\title{
Silver(I) and Copper(I) Complexes with a Schiff Base Derived from 2-Aminofluorene with Promising Antibacterial Activity
}

Olga L. Cifuentes-Vaca ${ }^{1,2}$, Juan Andrades-Lagos ${ }^{3}$, Javier Campanini-Salinas ${ }^{4}$, Antonio Laguna $^{1}$, David Vásquez-Velásquez ${ }^{3^{*}}$, and M. Concepción Gimeno ${ }^{1 *}$

1 Departamento de Química Inorgánica, Instituto de Síntesis Química y Catálisis Homogénea (ISQCH), Universidad de Zaragoza-CSIC, 50009 Zaragoza, Spain.

${ }^{2}$ Universidad Andrés Bello, sede Concepción, Departamento Ciencias Químicas, Facultad de Ciencias Exactas, Autopista Concepción-Talcahuano 7100.Talcahuano. Chile.

${ }^{3}$ Departamento de Química Farmacológica y Toxicológica, Facultad de Ciencias Químicas y Farmacéuticas, Universidad de Chile, Sergio Livingstone 1007, 8380492, Santiago, Chile.

${ }^{4}$ Facultad de Medicina y Ciencia, Universidad San Sebastián, Lago Panguipulli 1390, 5501842, Puerto Montt, Chile.

\section{ABSTRACT}

By reaction of 2-aminofluorene with 2-pyridinecarboxaldehyde a new Schiff base (L) is obtained. The reaction of this ligand with $\mathrm{Ag}(\mathrm{I})$ and $\mathrm{Cu}(\mathrm{I})$ salts in different stoichiometry leads to the complexes $\left[\mathrm{Ag}\left(\mathrm{CF}_{3} \mathrm{SO}_{3}\right)(\mathrm{L}) \mathrm{PPh}_{3}\right](\mathbf{1})$ or $\left[\mathrm{ML}_{2}\right] \mathrm{A}\left(\mathrm{M}=\mathrm{Ag}, \mathrm{Cu} ; \mathrm{A}=\mathrm{CF}_{3} \mathrm{SO}_{3}\right.$, $\mathrm{ClO}_{4}$ or $\mathrm{BF}_{4}$ ). Structural characterization by X-ray crystallography has been carried out for complexes $\left[\mathrm{AgL}_{2}\right] \mathrm{ClO}_{4}(4)$ and $\left[\mathrm{Ag}(\mathrm{L})\left(\mathrm{PPh}_{3}\right)_{2}\right]\left(\mathrm{CF}_{3} \mathrm{SO}_{3}\right)(6)$, which confirms the chelate nature of $\mathbf{L}$ and the presence of $\mathrm{Ag} \cdots \mathrm{H}$ interactions between two molecules. The biological studies show that Schiff base $\mathbf{L}$ presents antibacterial activity in Gram-positive bacteria and E. coli. The coordination to silver increases this activity, but the formation of the copper complex does not generate significant changes.

\section{Introduction}

Infectious diseases are a leading cause of death worldwide, and the mounting emergence of antibacterial resistance has contributed to rising rates of potentially-fatal infections. The bacteria implicated in these infections include the so-called ESKAPE pathogens, such as Enterococcus faecium, Staphylococcus aureus, Klebsiella pneumoniae, Acinetobacter baumannii, Pseudomonas aeruginosa, and various Enterobacter species [1,2]. Traditionally, development of new antibacterial molecules has been based mainly on two strategies: a) modifying or adding a small chemical group to an antibiotic already in clinical use, to improve some aspect of its pharmacodynamic and/or pharmacokinetic profile; or b) seeking new molecules from natural products that have demonstrated activity against resistant bacteria. Both strategies involve structural modifications or additions that preserve the pharmacophore and therefore maintain both the mechanism and site of action. 
Optimizing these compounds may be effective initially; however, due to the structural similarity of the novel and existing molecules, bacteria rapidly adapt their resistance mechanisms to thwart the new antibiotics [3].

New approaches should consider novel structures, no present in microorganisms. In this regard, the Schiff bases and their metal complexes play an important role in the bioinorganic chemistry due to their structural diversity and wide spectrum of their biological activities. A number of copper and silver complexes with Schiff bases have been already studied for antibacterial activity [4-14]. Actually, there is not a drug that incorporates a copper in their structure, but is available only one product with silver, silver sulfadiazine (SSD). The principal problem with SSD is a poor solubility, which is the reason because is presented in topical formulations.

The redox properties of copper can cause cellular damage. A number or mechanisms have been suggested. Reactive hydroxyl radicals can be generated in a Fenton-type reaction. The extremely reactive hydroxyl radical can participate in a number of reactions detrimental to cellular molecules, such as the oxidation of proteins and lipids [15]. Copper ions can also lead to depletion of sulfhydryls, such as in cysteines or glutathione. The hydrogen peroxide thus generated can in turn participate in redox reaction and lead to further generation of toxic hydroxyl radicals.

Silver has been known to possess antimicrobial properties for more than two thousand years and is considered a broad-spectrum antimicrobial agent [16]. It is well established that metallic silver causes minimum damage to a living organism and cationic $\mathrm{Ag}^{+}$is the biologically active species in applications of silver-containing compounds [16]. The antimicrobial properties of $\mathrm{Ag}^{+}$are mainly attributed to its ability to bind thiols on proteins and enzymes, block cellular respiration, cause cell membrane damage [16], and bind to nucleic acids [17]. In addition to silver salts, silver complexes derived from various ligands have regained attention as antimicrobial agents [18].

The structural versatility of the Schiff bases permits pharmacokinetic control to improve and the solubility of new compounds, and together with the known capacity to coordinate metals like copper and silver, with potent antibacterial activity, suggest that this compounds can give a new kind of antimicrobial drugs with interesting properties. Here we report the synthesis of a new kind of Schiff base and its complexes with copper and silver, that are water soluble and with high antibacterial activity.

\section{Results and discussion}

The preparation of the Schiff base $\mathbf{L}$ has been achieved, in good yield, by reaction of 2aminofluorene with 2-pyridinecarboxaldehyde in a 2:1 ratio in the presence of glacial acetic acid. In the FT-IR spectrum the vibration $v(C=N)_{\text {iminic }}=1625, v(C=N)_{p y}=1599\left(\mathrm{~cm}^{-1}\right)$. The 
resonances for ${ }^{1} \mathrm{H}$ and ${ }^{13} \mathrm{C}\left\{{ }^{1} \mathrm{H}\right\}$ NMR spectra agree with the proposed formulation (see Experimental section).

The coordination behavior of this ligand towards $\mathrm{Ag}(\mathrm{I})$ and $\mathrm{Cu}(\mathrm{I})$ compounds has been studied. In first place, the reaction of $\mathbf{L}$ with $\left[\mathrm{Ag}\left(\mathrm{CF}_{3} \mathrm{SO}_{3}\right) \mathrm{PPh}_{3}\right]$ leads to complex $\mathbf{1}$ in which the binding of the silver fragment to the two $\mathrm{N}$ groups is proposed (see Scheme 1). In the FT-IR spectrum the vibrations $v(C=N)_{\text {iminic }}$ and $v(C=N)_{\text {py }}$ appear at 1601 and 1587 $\mathrm{cm}^{-1}$, respectively. The presence of triflate and triphenylphosphine is confirmed by the corresponding bands due to these groups (see Experimental section). The ${ }^{19} \mathrm{~F}$ spectrum shows one signal at $-80.07 \mathrm{ppm}$ and the ${ }^{31} \mathrm{P}\{\mathrm{H}\}$ shows a singlet at $11.68 \mathrm{ppm}$. In the ${ }^{1} \mathrm{H}$ NMR spectra it is observed that the displacements of the $\mathrm{CH}$ groups attached to the nitrogen are shifted downfield by the coordination of the metal. The ratio $\mathrm{L} / \mathrm{PPh}_{3}$ is $1 / 1$.

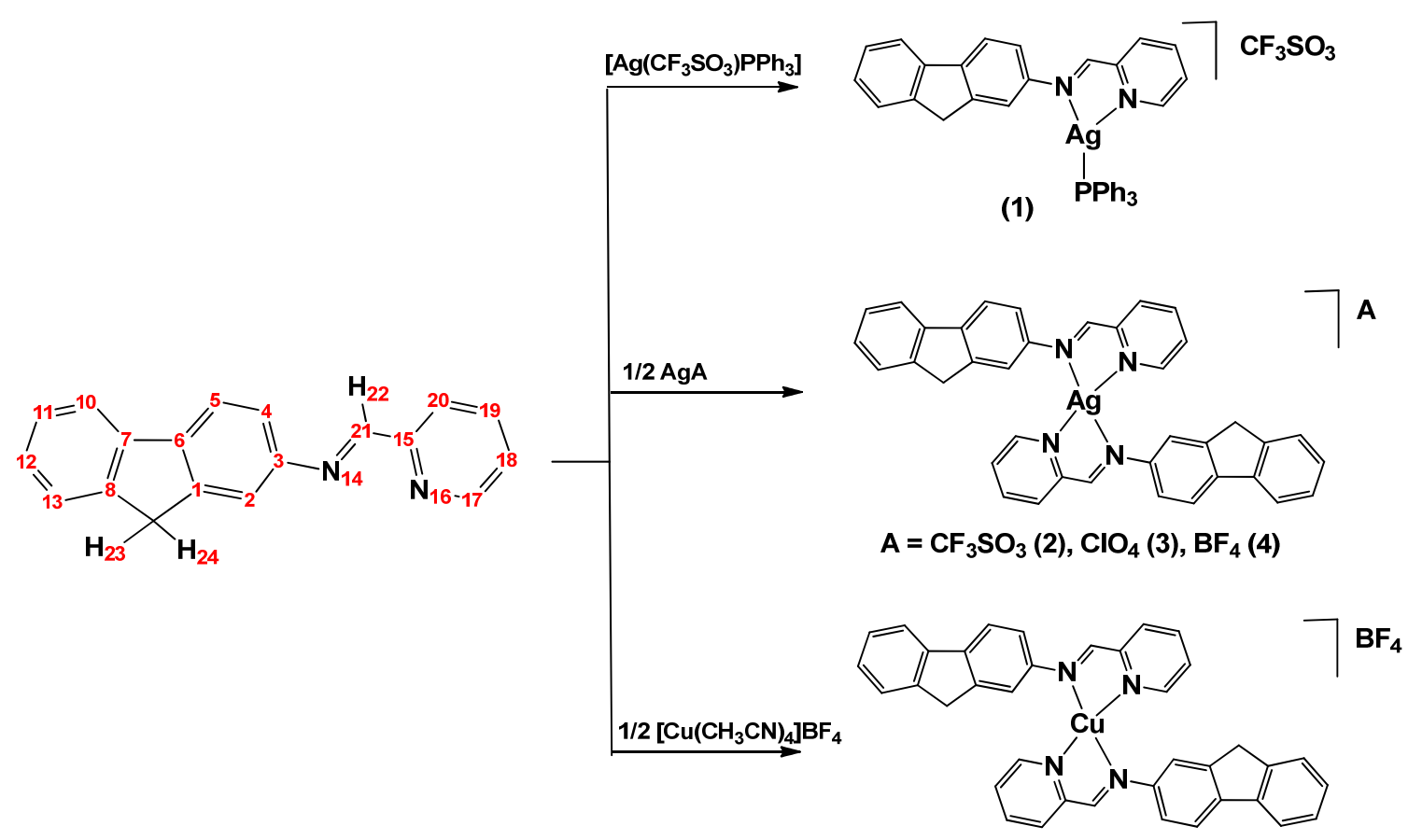

(5)

Scheme 1. Synthesis of the silver and copper complexes with the Schiff base $\mathbf{L}$.

The reaction of $\mathbf{L}$ with $\mathrm{AgA}\left(\mathrm{A}=\mathrm{CF}_{3} \mathrm{SO}_{3}, \mathrm{ClO}_{4}\right.$ or $\left.\mathrm{BF}_{4}\right)$ in a $2: 1$ ratio gives the complexes $\left[\mathrm{AgL}_{2}\right] \mathrm{A}(2-4)$ as yellow solids in good yield. In the ${ }^{1} \mathrm{H}$ and ${ }^{13} \mathrm{C} \mathrm{NMR}$ spectra, all signals corresponding to the ligand $\mathbf{L}$ are observed with a different chemical shift, and it is possible to see that the protons of the $\mathrm{CH}$ groups attached to the nitrogen undergo downfield displacements, due to the coordination of silver. In the fluorine NMR spectrum the signal 
for the triflate (2) and $\mathrm{BF}_{4}^{-}$(4) anions appears at -80.06 and $-153.37 \mathrm{ppm}$, respectively. The presence of the base $\mathbf{L}$ and the anions $\mathrm{CF}_{3} \mathrm{SO}_{3}{ }^{-}(2), \mathrm{ClO}_{4}{ }^{-}$(3) or $\mathrm{BF}_{4}^{-}$(4) is confirmed in the FT-IR spectra by the corresponding bands due to these groups (see Experimental section).

The coordination behavior of $\mathbf{L}$ towards copper(I) is similar and the reaction with $\left[\mathrm{Cu}\left(\mathrm{CH}_{3} \mathrm{CN}\right)_{4}\right] \mathrm{BF}_{4}$ (molar ratio 2:1) leads to $\left[\mathrm{CuL}_{2}\right] \mathrm{BF}_{4}$ (5). The FT-IR, ${ }^{1} \mathrm{H},{ }^{19} \mathrm{~F}$, and ${ }^{13} \mathrm{C}$ NMR spectra are very similar to that of the silver complex 4.

The crystal structure of complex $\mathbf{4}$ has been established by X-ray diffraction studies, and the cation can be seen in Figure 1. The silver center is found in a tetrahedral geometry bonded to two Schiff base ligands in an $\mathrm{N}^{\wedge} \mathrm{N}$ chelate fashion. The two planar ligands are located almost perpendicular one to each other. The Ag-N distances lye in the range Ag1 N4 2.2928(17) to Ag1 N3 2.386(2) $\AA$, which belongs to the two nitrogen atoms of one of the ligands. The bite angles of the ligands coordinated to the silver atom are quite narrow, $\mathrm{N} 1 \mathrm{Ag} 1 \mathrm{~N} 2$ 72.63(6), N4 Ag1 N3 72.86(7), and this causes the distorsion from the ideal tetrahedral geometry.

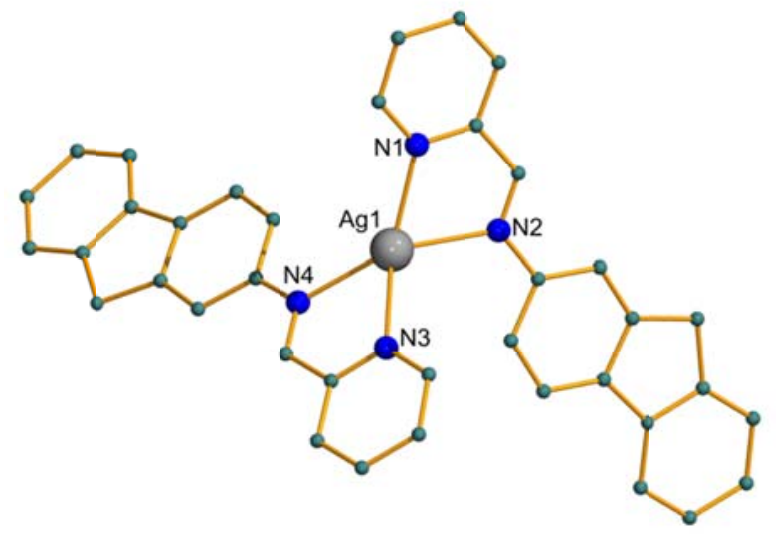

Figure 1. Molecular structure of the cation of complex 4. H atoms are omitted for clarity. Selected bond lengths $(\AA)$ and angles $\left({ }^{\circ}\right)$ : Ag1 N4 2.2928(17), Ag1 N1 2.3008(18), Ag1 N2 2.3482(18), Ag1 N3 2.386(2), N1 C1 1.331(3), N1 C5 1.355(3), N2 C6 1.274(3), N2 C7 1.418(3), N3 C20 1.333(3), N3 C24 1.345(3), N4 C25 1.273(3), N4 C26 1.425(3); N4 Ag1 N1 134.38(6), N4 Ag1 N2 141.74(6), N1 Ag1 N2 72.63(6), N4 Ag1 N3 72.86(7), N1 Ag1 N3 133.62(6), N2 Ag1 N3 109.79(7).

In the crystal of compound 4 several secondary interactions are observed between two adjacent molecules, originated by the hydrogen bonding between some of the hydrogen of the fluorene moiety of one molecule and the silver center of the other molecule, with distances $\operatorname{Ag}(1) \cdots \mathrm{H}(19)$ 2.761, $\operatorname{Ag}(1) \cdots \mathrm{H}(38)$ 2.777, $\operatorname{Ag}(1) \cdots \mathrm{H}(29) 2.818 \AA$ (Figure 2). 


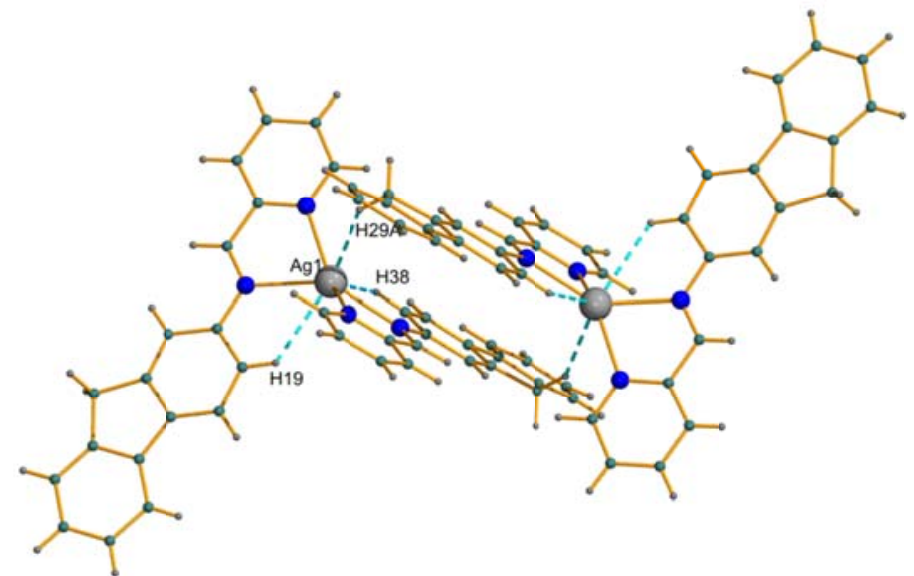

Figure 2. $\mathrm{Ag} \cdots \mathrm{H}$ hydrogen bonding in complex 4.

When $\left[\mathrm{Ag}\left(\mathrm{CF}_{3} \mathrm{SO}_{3}\right)(\mathrm{L})\left(\mathrm{PPh}_{3}\right)\right](\mathbf{1})$ was recrystallized, by slow diffusion of diethyl ether into a dichloromethane solution, suitable crystals for X-ray diffraction of the complex with two phosphines, $\left[\mathrm{Ag}(\mathrm{L})\left(\mathrm{PPh}_{3}\right)_{2}\right]\left(\mathrm{CF}_{3} \mathrm{SO}_{3}\right)$ (6), was obtained, see Figure 3. The complex crystallizes with two independent molecules per asymmetric unit. The silver center is found in a tetrahedral geometry bonded to the chelate ligand and to two phosphine moieties. The Ag- N bond lengths are Ag1-N2 2.316(3) and Ag1-N1 2.366(3), which are similar to those found in complex 4. The Ag-P distances Ag-P2 2.4274(10) and Ag1-P1 2.4350(10) are also normal for these type of compounds. The bite angle of the Schiff base ligand, N2-Ag1-N1 71.54(9)o, is narrower than those in complex 4

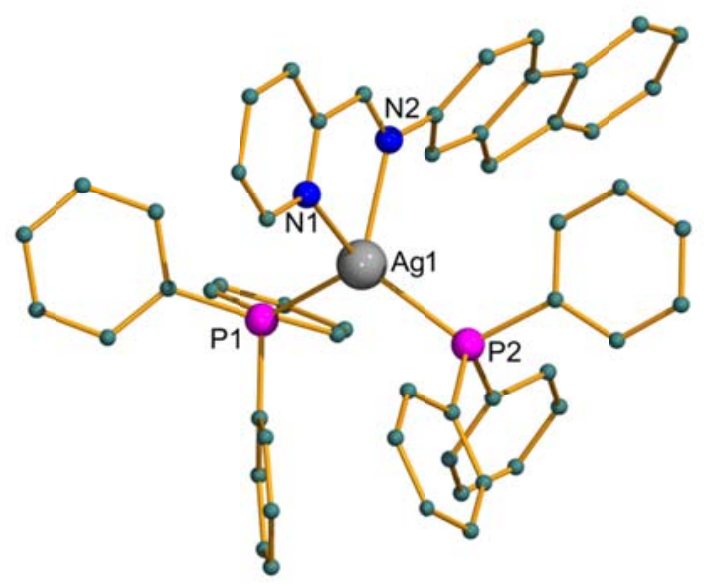

Figure 3. Molecular structure of the cation of complex 6. Hydrogen atoms are omitted for clarity. Selected bond lengths $(\AA)$ and angles $\left(^{\circ}\right)$ : Ag1 N2 2.316(3), Ag1 N1 2.366(3), Ag P2 2.4274(10), Ag1 P1 2.4350(10); N2 Ag1 N1 71.54(9), N2 Ag1 P2 115.57(7), N1 Ag1 P2 119.47(6), N2 Ag1 P1 117.28(7), N1 Ag1 P1 109.16(7), P2 Ag1 P1 116.21(4).

\subsection{Biological studies}


The results of screening for antibacterial activity are shown in Table 1

Table 1: Antibacterial Activity results.

\begin{tabular}{c|cccccc}
\hline \multirow{3}{*}{ Compound } & MSSA & MRSA & E. faecalis & E.coli & P.aeruginosa & K.pneumoniae \\
L1 & 256 & 256 & 256 & 256 & $>256$ & $>256$ \\
$\mathbf{1}$ & 8 & 8 & 8 & 8 & 8 & 32 \\
$\mathbf{2}$ & 64 & 64 & 64 & 16 & 16 & 32 \\
$\mathbf{3}$ & 64 & 64 & 64 & 8 & 16 & 32 \\
$\mathbf{4}$ & 64 & 64 & 32 & 8 & 16 & 32 \\
$\mathbf{5}$ & 256 & 256 & 256 & 256 & 256 & $>256$ \\
vancomycin & 1 & 1 & 2 & - & - & - \\
gentamicin & - & - & - & 0.5 & 1 & 2 \\
\hline
\end{tabular}

The results show that the $\mathbf{L}$ ligand has antibacterial activity in bacteria MSSA, MRSA, $E$. faecalis and in E. coli at $256 \mu \mathrm{g} / \mathrm{mL}$, nevertheless, no activity was observed in $P$. aeruginosa and K. pneumoniae. The compounds 1-4 have good activity against all bacteria studied, were 1 present the highest activity of the silver complexes group. Compound $\mathbf{5}$ (copper complex) have a MIC of $256 \mu \mathrm{g} / \mathrm{mL}$ in five of the bacteria, except in $K$. pneumoniae where is inactive.

The ligand $\mathbf{L}$ is common in all the complexes 1-5, and shows a week activity in antibacterial screening. However, when $\mathbf{L}$ is complexed with silver to get compound $\mathbf{1}$, the activity increases significatively, but the addition of a second $\mathbf{L}$ ligand reduce the antibacterial activity 2 or 8 times (compounds 2-4). Into the compounds constituted with two $\mathbf{L}$ and silver atom; we found different activities depending on the counterion. In comparison with compound $\mathbf{1}$, the activity against Gram-positive bacteria of complexes $\mathbf{2}$ and 4 is reduced 4-8 times, however, in Gram-negative bacteria the antibacterial effect down only two times. Interestingly, the MIC value for compound $\mathbf{4}$ against $E$. coli does not change respect to $\mathbf{1}$. Comparing compound 1 with 2 , the main structural difference is the change of the ligand $\mathrm{PPh}_{3}$ for $\mathbf{L}$ and that produce a fall in activity from 8 to $64 \mu \mathrm{g} / \mathrm{mL}$. The bactericidal activity of silver compounds can be attributed to two different properties, first, the ability to generate ROS and second their affinity to associate closely with R-SH groups. The silver ions can easily bind to SH groups, such as in cysteine, which can directly disrupt the function of specific enzymes or break $\mathrm{S}-\mathrm{S}$ bridges necessary to maintain the integrity of folded proteins, causing detrimental effects to the metabolism and physiology of the cell [19]. The bind to SH groups requires a silver ion-free or available to react; this can explain the highest activity of 1 compared with 2-4. In $\mathbf{1}$, the silver atom has less steric hindrance than compounds 2-4. The two $\mathbf{L}$ ligands surround the silver ion hamper the reaction with $\mathrm{SH}$ groups. It is interesting to observe that the replacement of the silver atom by copper, decrease the activity dramatically (compare compound $\mathbf{4}$ and 5 in Table 1). The differences 
in the antimicrobial potency of silver and copper ions can be explained by the cysteine affinity and homeostasis. The copper ions have a higher affinity to cysteine as compared to silver ions [20]. However, the difference in the activity of the copper or silver ions could be based in the fact that copper is an essential element and cells possess mechanisms to maintain its homeostasis by avoiding its intracellular toxicity. On the other hand, silver ion is not an essential element and, by irreversibly binding the cysteines, it can poison vital enzymatic systems, such as the main energy source of the cells or the respiratory electron transport chains.

\section{Conclusions}

A Schiff base derived from 2-Aminofluorene has been prepared and the coordination behavior of this new ligand towards silver and copper salts has been studied. Coordination through the two nitrogen atoms to the metals is proposed for all the complexes and confirmed by X-ray diffraction for two of them, thus the chelate nature of the Schiff base $\mathbf{L}$ has been correborated in the structure of $\left[\mathrm{Ag}(\mathrm{L})_{2}\right]\left(\mathrm{ClO}_{4}\right)(4)$ or in $\left[\mathrm{Ag}(\mathrm{L})\left(\mathrm{PPh}_{3}\right)_{2}\right]\left(\mathrm{CF}_{3} \mathrm{SO}_{3}\right)$ (6), obtained in the crystallization of $\mathbf{1}$. In addition $\mathrm{Ag} \cdots \mathrm{H}$ hydrogen bonding interactions are found between two molecules of compound $\mathbf{4}$.

The biological studies show that $\mathbf{L}$ presents antibacterial activity in Gram-positive bacteria (MSSA, MRSA, and E. faecalis) and E. coli at $256 \mu \mathrm{g} / \mathrm{mL}$. The formation of silver complexes generate active compounds in all evaluated bacteria, with marked differences in antibacterial activity with increases up to 32 -fold when compared to $\mathbf{L}$. The formation of a copper complex does not generate significant changes in antibacterial activity, since it retain the MIC value of $\mathbf{L}$ in MSSA, MRSA, E. faecalis, and E. coli and only slightly improving the activity in $P$. aeruginosa $(\mathrm{MIC}=256 \mu \mathrm{g} / \mathrm{mL}$ ). This compound had no activity in K. Pneumoniae.

\section{Experimental}

\subsection{General information}

${ }^{1} \mathrm{H}$ and ${ }^{13} \mathrm{C}\left\{{ }^{1} \mathrm{H}\right\}$ NMR spectra were recorded at room temperature on a BRUKER AVANCE 400 spectrometer $\left({ }^{1} \mathrm{H}, 400 \mathrm{MHz},{ }^{13} \mathrm{C}, 100.6 \mathrm{MHz}\right) .2$-aminofluorene and 2pyridinecarboxaldehyde were obtained from Aldrich and were used without further purification.

\subsection{Synthesis of the Schiff Base $\mathbf{L}$}

To a solution of 2-aminofluorene $(0.568 \mathrm{~g}, 3.15 \mathrm{mmol})$ in $20 \mathrm{ml}$ of $\mathrm{CHCl}_{3}, 2$ pyridinecarboxaldehyde $(0.200 \mathrm{~g}, 1.88 \mathrm{mmol})$ in $\mathrm{CHCl}_{3}(10 \mathrm{~mL})$ and glacial acetic acid $(0.6 \mathrm{~mL})$ were added and the mixture was stirred for 8 days at refluxing temperature and protected from light. Afterwards he solution was evaporated under reduced pressure and the solid was washed with diethyl ether and n-hexane; a yellow solid was obtained, (Yield 
81.4\%). FT-IR $\left(\mathrm{cm}^{-1}\right): v(\mathrm{C}=\mathrm{N})_{\text {iminic }}=1625, v(\mathrm{C}=\mathrm{N})_{\mathrm{py}}=1599 .{ }^{1} \mathrm{H}$ NMR (acetone-d6) $\delta$ (ppm): 8.70 (ddd, $\left.\mathrm{H}_{17}, \mathrm{~J}=4,8 \mathrm{~Hz}, 1 \mathrm{H}\right), 8.68\left(\mathrm{~m}, \mathrm{H}_{22}, 1 \mathrm{H}\right), 8.24\left(\mathrm{dt}, \mathrm{H}_{19}, \mathrm{~J}=7.9 \mathrm{~Hz}, 1 \mathrm{H}\right)$, 7.91 (m, $\left.\mathrm{H}_{20,5,10}, 3 \mathrm{H}\right), 7.57$ (m, $\left.\mathrm{H}_{2,18}, 2 \mathrm{H}\right), 7.38-7.28\left(\mathrm{~m}, \mathrm{H}_{4,11,12,13}, 4 \mathrm{H}\right), 3.95\left(\mathrm{~s}, \mathrm{H}_{23,24}, 2 \mathrm{H}\right)$. ${ }^{13} \mathrm{C}$ APT-NMR (acetone-d6) $\delta(\mathrm{ppm}): 160.85\left(\mathrm{C}_{21}\right), 155.85\left(\mathrm{C}_{15}\right), 150.85\left(\mathrm{C}_{3}\right), 150.61$ $\left(\mathrm{C}_{17}\right), 145.56\left(\mathrm{C}_{8}\right), 144.61\left(\mathrm{C}_{1}\right), 142.05\left(\mathrm{C}_{7}\right), 141.45\left(\mathrm{C}_{6}\right), 137.61\left(\mathrm{C}_{19}\right), 127.76\left(\mathrm{C}_{18}\right)$, $126.14\left(\mathrm{C}_{12,13,11}\right), 121.87\left(\mathrm{C}_{20}\right), 121.47\left(\mathrm{C}_{10}\right), 121.33\left(\mathrm{C}_{4}\right), 120.74\left(\mathrm{C}_{2}\right), 118.72\left(\mathrm{C}_{5}\right), 37.44$ $\left(\mathrm{C}_{9}\right)$.

\subsection{Synthesis of the complexes $\mathbf{1 - 5}$}

To a solution of $0.5 \mathrm{mmol}$ of $\left[\mathrm{Ag}\left(\mathrm{CF}_{3} \mathrm{SO}_{3}\right) \mathrm{PPh}_{3}\right](0.259 \mathrm{~g}), \mathrm{Ag}\left(\mathrm{CF}_{3} \mathrm{SO}_{3}\right)(0.128 \mathrm{~g})$, $\mathrm{Ag}\left(\mathrm{ClO}_{4}\right)(0.103 \mathrm{~g}), \mathrm{Ag}\left(\mathrm{BF}_{4}\right)(0.097 \mathrm{~g})$, or $\left[\mathrm{Cu}\left(\mathrm{CH}_{3} \mathrm{CN}\right)_{4}\right] \mathrm{BF}_{4}(0.57 \mathrm{~g})$ in $20 \mathrm{~mL}$ of acetone (2), dichloromethane (1, 3 or 4) or ethanol (5), a stoichiometric amount of the Schiff base $\mathbf{L}(0,135 \mathrm{~g}, 0.5 \mathrm{mmol})$ was added. The mixture was stirred at room temperature for 1 hour and it was protected from light. The solution was evaporated under reduced pressure to a small volume $(3 \mathrm{~mL})$. The solid was washed with diethyl ether and n-hexane:

[Ag $\left.\left(\mathrm{CF}_{3} \mathrm{SO}_{3}\right)(\mathrm{L}) \mathrm{PPh}_{3}\right]$ (1) was isolated as a yellow solid, $94.3 \%$ yield. FT-IR $\left(\mathrm{cm}^{-1}\right)$ : $v(\mathrm{C}=\mathrm{N})_{\text {imínic }}=1601 ; v(\mathrm{C}-\mathrm{N})_{\mathrm{py}}=1587 ;\left(\mathrm{CF}_{3} \mathrm{SO}_{3}\right)=1261,1140,1039,562,506 ;\left(\mathrm{PPh}_{3}\right)=$ 1086, 697, 641. ${ }^{19} \mathrm{~F}$ NMR (acetone-d6), $\delta$ (ppm): - 80.07 (s). ${ }^{31} \mathrm{P}\{\mathrm{H}\}$ NMR (acetone-d6), $\delta$ (ppm): 11.68 (s); ${ }^{1} \mathrm{H}$ NMR (acetone-d6), $\delta$ (ppm): 9,00 (s, $\left.\mathrm{H}_{22}, 1 \mathrm{H}\right) ; 8.77$ (dd, $\mathrm{H}_{17}, \mathrm{~J}=3.5$ $\mathrm{Hz}, 1 \mathrm{H}) ; 8.25$ (dt, $\left.\mathrm{H}_{19}, \mathrm{~J}=7,8 \mathrm{~Hz}, 1 \mathrm{H}\right) ; 8.15$ (td, $\left.\mathrm{H}_{20}, \mathrm{~J}=7.7 \mathrm{~Hz}, 1 \mathrm{H}\right) ; 7,90$ (d, H, $\mathrm{H}_{5,10}, \mathrm{~J}=$ $7,8 \mathrm{~Hz}, 2 \mathrm{H}) ; 7.61\left(\mathrm{~m}, \mathrm{H}_{2,18}, \mathrm{~J}=7,6 \mathrm{~Hz}, 2 \mathrm{H}\right) ; 7.50$ (m, $\left.\mathrm{H}_{4,11,12,13}, 4 \mathrm{H}\right) ; 7.37\left(\mathrm{~m}, \mathrm{PPh}_{3}, 15 \mathrm{H}\right)$; $3.71\left(\mathrm{~s}, \mathrm{H}_{23,24}, 2 \mathrm{H}\right) .{ }^{13} \mathrm{C}-\mathrm{APT}$ NMR (acetone-d6), $\delta(\mathrm{ppm})$ : $160.52\left(\mathrm{C}_{21}\right), 153.28\left(\mathrm{C}_{15}\right)$, $149.06\left(\mathrm{C}_{3}\right), 151.66\left(\mathrm{C}_{17}\right), 145.61\left(\mathrm{C}_{8}\right), 144.61\left(\mathrm{C}_{1}\right), 142.49\left(\mathrm{C}_{7}\right), 141.45\left(\mathrm{C}_{6}\right), 139.35\left(\mathrm{C}_{19}\right)$, $134.43\left(\mathrm{C}_{\text {orthoPPh3 }}\right), 132.81$ ( $\left.\mathrm{C}_{\text {ipsoPPh3 }}\right) .131 .65\left(\mathrm{C}_{18}\right), 130.16\left(\mathrm{C}_{\text {meta,paraPPh3 }}\right), 127.88\left(\mathrm{C}_{12,13,11}\right)$, $126.07\left(\mathrm{C}_{20}\right), 121.83\left(\mathrm{C}_{10}\right), 121.44\left(\mathrm{C}_{4}\right), 121.01\left(\mathrm{C}_{2}\right), 119.91\left(\mathrm{C}_{5}\right), 37.44\left(\mathrm{C}_{9}\right)$.

$\left[\mathrm{AgL}_{2}\right]\left(\mathrm{CF}_{3} \mathrm{SO}_{3}\right)$ (2) was isolated as yellow solid, $95.0 \%$ yield. FT-IR $\left(\mathrm{cm}^{-1}\right): v(\mathrm{C}=\mathrm{N})_{\text {imínic }}$ $=1585, \mathrm{v}(\mathrm{C}-\mathrm{N})_{\mathrm{py}}=1560 ;\left(\mathrm{CF}_{3} \mathrm{SO}_{3}\right)=1269,1149,1029,572,516 .{ }^{19} \mathrm{~F}$ NMR (acetone-d6), $\delta$ (ppm): - 80.06 (s); ${ }^{1} \mathrm{H}$ NMR (acetone-d6), $\delta$ (ppm): 9.33 (s, $\left.\mathrm{H}_{22}, 2 \mathrm{H}\right) ; 8.96\left(\mathrm{~d}, \mathrm{H}_{17}, \mathrm{~J}=4.8\right.$ $\mathrm{Hz}, 2 \mathrm{H}) ; 8.34$ (d, $\left.\mathrm{H}_{19}, \mathrm{~J}=7.7 \mathrm{~Hz}, 2 \mathrm{H}\right) ; 8.26$ (d, $\left.\mathrm{H}_{20}, \mathrm{~J}=7.0 \mathrm{~Hz}, 2 \mathrm{H}\right) ; 7-88-7.85$ (m, $\left.\mathrm{H}_{5,10,2,18}, 8 \mathrm{H}\right) ; 7.64$ (m, H $\left.\mathrm{H}_{4}, 2 \mathrm{H}\right) ; 7.53$ (dt, $\left.\mathrm{H}_{13}, \mathrm{~J}=7.4 \mathrm{~Hz}, 2 \mathrm{H}\right) ; 7.35\left(\mathrm{~m}, \mathrm{H}_{11,12}, 4 \mathrm{H}\right) ; 3.84$ $\left(\mathrm{s}, \mathrm{H}_{23,24}, 4 \mathrm{H}\right) .{ }^{13} \mathrm{C}$-APT NMR (acetone-d6), $\delta(\mathrm{ppm}): 159.10\left(\mathrm{C}_{21}\right), 151.17\left(\mathrm{C}_{15}\right), 147.60$ $\left(\mathrm{C}_{3}\right), 152.77\left(\mathrm{C}_{17}\right), 145.75\left(\mathrm{C}_{8}\right), 144.71\left(\mathrm{C}_{1}\right), 143.29\left(\mathrm{C}_{7}\right), 141.39\left(\mathrm{C}_{6}\right), 140.64\left(\mathrm{C}_{19}\right), 130.29$ $\left(\mathrm{C}_{18}\right), 129.20\left(\mathrm{C}_{12}\right), 128.24\left(\mathrm{C}_{13}\right), 127.89\left(\mathrm{C}_{11}\right), 126.03\left(\mathrm{C}_{20}\right), 123.24\left(\mathrm{C}_{10}\right), 121.52\left(\mathrm{C}_{4}\right)$, $121.10\left(\mathrm{C}_{2}\right), 119.75\left(\mathrm{C}_{5}\right), 37.35\left(\mathrm{C}_{9}\right)$.

$\left[\mathrm{AgL}_{2}\right]\left(\mathrm{ClO}_{4}\right)$ (3) was isolated as yellow solid, $51.69 \%$ yield. FT-IR $\left(\mathrm{cm}^{-1}\right): v(\mathrm{C}=\mathrm{N})_{\text {imínic }}=$ $1624, v(\mathrm{C}-\mathrm{N})_{\mathrm{py}}=1589 ;\left(\mathrm{ClO}_{4}\right)=924 .{ }^{1} \mathrm{H} \mathrm{NMR}\left(\right.$ acetone-d6), $\delta(\mathrm{ppm}): 9.31\left(\mathrm{~s}, \mathrm{H}_{22}, 2 \mathrm{H}\right)$; $8.94\left(\mathrm{~s}, \mathrm{H}_{17}, \mathrm{~J}=4.7 \mathrm{~Hz} ; 2 \mathrm{H}\right) ; 8.32\left(\mathrm{dd}, \mathrm{H}_{19}, \mathrm{~J}=7.7 \mathrm{~Hz}, 2 \mathrm{H}\right) ; 8.23\left(\mathrm{dd}, \mathrm{H}_{20}, \mathrm{~J}=7.7 \mathrm{~Hz}, 2 \mathrm{H}\right)$; $7.83\left(\mathrm{~m}, \mathrm{H}_{5,10,2,18} ; 8 \mathrm{H}_{8}\right) ; 7.63\left(\mathrm{dd}, \mathrm{H}_{4}, \mathrm{~J}=8.1 \mathrm{~Hz}, 2 \mathrm{H}\right) ; 7.51\left(\mathrm{~d}, \mathrm{H}_{13}, \mathrm{~J}=7.5 \mathrm{~Hz}, 2 \mathrm{H}\right) ; 7.31$ 
(m, $\left.\mathrm{H}_{11,12}, 4 \mathrm{H}\right) ; 3.82\left(\mathrm{~s}, \mathrm{H}_{23,24}, 4 \mathrm{H}\right) .{ }^{13} \mathrm{C}$-APT NMR (acetone-d6), $\delta(\mathrm{ppm}): 159.05\left(\mathrm{C}_{21}\right)$, $151.03\left(\mathrm{C}_{15}\right), 147.51\left(\mathrm{C}_{3}\right), 152.82\left(\mathrm{C}_{17}\right), 145.75\left(\mathrm{C}_{8}\right), 144.72\left(\mathrm{C}_{1}\right), 143.33\left(\mathrm{C}_{7}\right), 141.38\left(\mathrm{C}_{6}\right)$, $140.71\left(\mathrm{C}_{19}\right), 130.51\left(\mathrm{C}_{18}\right), 129.28\left(\mathrm{C}_{12}\right), 128.24\left(\mathrm{C}_{13}\right), 127.89\left(\mathrm{C}_{11}\right), 126.03\left(\mathrm{C}_{20}\right), 123.30$ $\left(\mathrm{C}_{10}\right), 121.52\left(\mathrm{C}_{4}\right), 121.11\left(\mathrm{C}_{2}\right), 119.75\left(\mathrm{C}_{5}\right), 37.35\left(\mathrm{C}_{9}\right)$.

$\left[\mathrm{AgL}_{2}\right]\left(\mathrm{BF}_{4}\right)(4)$ was isolated as yellow solid, $65.58 \%$ yield. FT-IR $\left(\mathrm{cm}^{-1}\right): v(\mathrm{C}=\mathrm{N})_{\text {imínic }}=$ $1588, v(\mathrm{C}-\mathrm{N})_{\mathrm{py}}=1561 ;\left(\mathrm{BF}_{4}\right)=1007,731,518 .{ }^{19} \mathrm{~F}$ NMR (acetone-d6), $\delta(\mathrm{ppm}):-153.37$ (s). ${ }^{1} \mathrm{H}$ NMR (acetone-d6), $\delta$ (ppm): $9.20\left(\mathrm{~s}, \mathrm{H}_{22}, 2 \mathrm{H}\right) ; 8.83\left(\mathrm{~m}, \mathrm{H}_{17}, 2 \mathrm{H}\right) ; 8.23\left(\mathrm{td}, \mathrm{H}_{19}, \mathrm{~J}=\right.$ $7.7 \mathrm{~Hz}, 2 \mathrm{H}) ; 8.13$ (dd, $\left.\mathrm{H}_{20}, \mathrm{~J}=6.7 \mathrm{~Hz}, 2 \mathrm{H}\right) ; 7.72\left(\mathrm{~m}, \mathrm{H}_{5,10,2,18}, 8 \mathrm{H}\right) ; 7.52$ (dd, $\mathrm{H}_{4}, \mathrm{~J}=8.1$ $\mathrm{Hz}, 2 \mathrm{H}) ; 7.40-7.21$ (m, $\left.\mathrm{H}_{13,11 \mathrm{y} 12}, 6 \mathrm{H}\right) ; 3.71$ (s, $\left.\mathrm{H}_{23,24}, 4 \mathrm{H}\right) .{ }^{13} \mathrm{C}-\mathrm{APT}$ (acetone-d6), $\delta$ (ppm): $159.07\left(\mathrm{C}_{21}\right), 151.08\left(\mathrm{C}_{15}\right), 147.53\left(\mathrm{C}_{3}\right), 152.80\left(\mathrm{C}_{17}\right), 145.75\left(\mathrm{C}_{8}\right), 144.72\left(\mathrm{C}_{1}\right), 143.32$ $\left(\mathrm{C}_{7}\right), 141.38\left(\mathrm{C}_{6}\right), 140.69\left(\mathrm{C}_{19}\right), 130.45\left(\mathrm{C}_{18}\right), 129.26\left(\mathrm{C}_{12}\right), 128.24\left(\mathrm{C}_{13}\right), 127.89\left(\mathrm{C}_{11}\right)$, $126.03\left(\mathrm{C}_{20}\right), 123.28\left(\mathrm{C}_{10}\right), 121.52\left(\mathrm{C}_{4}\right), 121.10\left(\mathrm{C}_{2}\right), 119.78\left(\mathrm{C}_{5}\right), 37.35\left(\mathrm{C}_{9}\right)$.

$\left[\mathrm{CuL}_{2}\right]\left(\mathrm{BF}_{4}\right)(5)$ was isolated as yellow solid, $46,42 \%$ yield. FT-IR $\left(\mathrm{cm}^{-1}\right): v(\mathrm{C}=\mathrm{N})_{\text {imínic }}=$ $1598, v(\mathrm{C}-\mathrm{N})_{\mathrm{py}}=1582 ;\left(\mathrm{BF}_{4}\right)=1017,772,514 .{ }^{19} \mathrm{~F}$ NMR (acetone-d6), $\delta(\mathrm{ppm}):-153.37$ (s). ${ }^{1} \mathrm{H}$ NMR (acetone-d6), $\delta$ (ppm): 9.53 (s, $\left.\mathrm{H}_{22}, 2 \mathrm{H}\right) ; 8.79$ (s, $\left.\mathrm{H}_{17}, 2 \mathrm{H}\right) ; 8.31\left(\mathrm{~s}, \mathrm{H}_{19,20}, 4 \mathrm{H}\right)$; 7.79-7.52 (m, $\left.\mathrm{H}_{5,10,2,18,4,13}, 12 \mathrm{H}\right) ; 7.35\left(\mathrm{~s}, \mathrm{H}_{11,12}, 4 \mathrm{H}\right) ; 3.82\left(\mathrm{~s}, \mathrm{H}_{23,24}, 4 \mathrm{H}\right) .{ }^{13} \mathrm{C}-\mathrm{APT}$ NMR (acetone-d6), $\delta(\mathrm{ppm}): 155.60\left(\mathrm{C}_{21}\right), 149.53\left(\mathrm{C}_{15}\right), 148,15\left(\mathrm{C}_{3}\right), 152.80\left(\mathrm{C}_{17}\right), 145.82\left(\mathrm{C}_{8}\right)$, $144.77\left(\mathrm{C}_{1}\right), 143.51\left(\mathrm{C}_{7}\right), 141.31\left(\mathrm{C}_{6}\right), 145.15\left(\mathrm{C}_{19}\right), 128.14\left(\mathrm{C}_{18}\right) .127 .80\left(\mathrm{C}_{12}\right), 127.35$ $\left(\mathrm{C}_{13}, \mathrm{C}_{11}\right), 125.77\left(\mathrm{C}_{20}\right), 121.03\left(\mathrm{C}_{10}\right), 119.81\left(\mathrm{C}_{4}\right), 118.99\left(\mathrm{C}_{5,2}\right), 37.24\left(\mathrm{C}_{9}\right)$.

\subsection{Crystal structure determination}

Suitable crystals for X-ray diffraction of $\left[\mathrm{Ag}(\mathrm{L})_{2}\right]\left(\mathrm{ClO}_{4}\right)(4)$ and $\left[\mathrm{Ag}(\mathrm{L})\left(\mathrm{PPh}_{3}\right)_{2}\right]\left(\mathrm{CF}_{3} \mathrm{SO}_{3}\right)$ (6) were grown by slow diffusion of diethyl ether into a dichloromethane solution of the complex $\mathbf{4}$ or $\mathbf{1}$, respectively. The crystal was mounted in inert oil on glass fibers and transferred to the cold gas stream of Xcalibur Oxford Diffraction diffractometer equipped with a low-temperature attachment. Data were collected using monochromated Mo K $\alpha$ radiation $(\mathrm{k}=0.71073 \AA)$, scan type $\mathrm{x}$. Absorption corrections based on multiple scans were applied with the SCALE3 ABSPACK scaling algorithm [21]. The structure was refined on F2 using the program SHELXL [22]. All non-hydrogen atoms were refined anisotropically. Hydrogen atoms were included using a riding model. CCDC reference numbers 1895607 (4) and 1895608 (6).

\subsection{Bacterial strains}

For the screening of antibacterial activity, the following strains were used: methicillinresistant Staphylococcus aureus (MRSA) ATCC 43300, methicillin-susceptible Staphylococcus aureus (MSSA) ATCC 29213, Enterococcus faecalis (E.faecalis) ATCC 29212, Eschericha coli (E.coli) ATCC 25922, Pseudomonas aeruginosa (P.aeruginosa) ATCC 27853 and Klebsiella pneumoniae (K.pneumoniae) ATCC 700603. 


\subsection{Antibacterial testing}

The Minimum Inhibitory Concentrations (MIC) was determined using a broth microdilution method, according to Clinical and Laboratory Standards Institute (CLSI) [23]. Vancomycin and gentamycin were used as quality control, according to MIC ranges reported by CLSI [24]. All compounds tested were dissolved in water with dimethyl sulfoxide (DMSO), not exceeding 1\% for well. The inoculum was prepared to a turbidity equivalent of $0.5 \mathrm{McFarland}$ standard, diluted in broth media to give a final concentration of $5 \times 10^{5} \mathrm{CFU} / \mathrm{mL}$ in the test tray; they were covered and placed in plastic bags to prevent evaporation. The plates were incubated at $35^{\circ} \mathrm{C}$ for $18-20 \mathrm{~h}$. The MIC was defined as the lowest concentration of compound giving complete inhibition of visible growth. All the experiments were performed three times in triplicate. The MIC values for all tested compounds and reference drug are listed in table 1.

\section{Acknowledgements}

The authors thank the Ministerio de Ciencia, Innovacion y Universidades (CTQ2016-75816-C2-1P) and Gobierno de Aragon- Fondo Social Europeo (E07_17R) for financial support. O. L. Cifuentes-Vaca thanks the CONOCYT for a postdoctoral Beca Chile. J. Campanini-Salinas and J. Andrades-Lagos. thanks to CONICYT Beca Doctorado Nacional No. 21130643 and 21130628, respectively.

\section{References}

[1] H.W. Boucher, G.H. Talbot, J.S. Bradley, J.E Edwards, D. Gilbert, L.B Rice, M. Scheld, B. Spellberg, J. Bartlett, Clin. Infect. Dis. 48 (2009) 1.

[2] World Health Organization. Global priority list of antibiotic-resistant bacteria to guide research, discovery, and development of new antibiotics. (2018) 7. http://www.who.int/medicines/publications/WHO-PPL-Short Summary 25Feb-ET NM WHO.pdf

[3] D.T. Moir, T.J. Opperman, M.M. Butler, T. L Bowlin, Curr. Opin. Pharmacol. 12 (2012) 535.

[4] N.K. Chaudhary, P. Mishra, Bioinorg. Chem. Appl. (2017) ID6927675.

[5] K. Das, C. Patra, C. Sen, A. Datta, C. Massera, E. Garribba, M.S. El Fallah, B.B. Beyene, C.H. Hung, C. Sinha, T. Askun, P. Celikboyun, D. Escudero, A. Frontera, J. Biol. Inorg. Chem. 22 (2017) 481.

[6] K. Dhahagani, M.P. Kesavan, K. Gujuluva-Gangatharan-Vinoth, L. Ravi, G. Rajagopal, J. Rajesh, Mater. Sci. Eng. C Mater. Biol. Appl. 90 (2018) 119.

[7] V.V. Dhayabaran, T.D. Prakash, Luminescence. 32 (2017) 1339. 
[8] N. Ganji, V.K. Chityala, P.K. Marri, R. Aveli, V. Narendrula, S. Daravath, Shivaraj, J. Photochem. Photobiol. B. 175 (2017) 132.

[9] P. Gull, B.A. Babgi, A.A. Hashmi, Microb. Pathog. 110 (2017) 444.

[10] P. Gull, M.A. Malik, O.A. Dar, A.A. Hashmi, Microb. Phatog. 104 (2017) 212.

[11] J. Jimenez, I. Chakraborty, M. Rojas-Andrade, P.K. Mascharak, J. Inorg. Biochem. 168 (2017) 13.

[12] S.A. Khan, S.A.A. Nami, S.A. Bhat, A. Kareem, N. Nishat, Microb. Pathog. 110 (2017) 414.

[13] Z. Parsaee, E. Joukar-Bahaderani, A. Afandak; Ultrason. Sonochem. 40 (2018) 629.

[14] P.P. Utthra, N. Raman, Int. J. Biol. Macromol. 116 (2018) 194.

[15] Y. Yoshida, S. Furuta, E. Niki, Biochim. Biophys. Acta 1210 (1993) 81.

[16] J. Fong, F. Wood, Int. J. Nanomedicine, 1 (2006) 441.

[17] J.L. Whitton, F. Hundley, B. O'Donnell, U. Desselberger, J. Virol. Methods, 7 (1983) 185.

[18] M.I. Azócar, G. Gómez, P. Levín, M. Paez, H. Muñoz, N. Dinamarca, J. Coord. Chem. 67 (2014) 3840.

[19] Y.N. Slavin, J. Asnis, U.O. Häfeli, H. Bach, J. Nanobiotechnology, 15 (2017) 65.

[20] G. Berthon, Critical evaluation of the stability constants of metal complexes of amino acids with polar side chains (Technical Report), Pure and Applied Chemistry, 1995, pp. 1117.

[21] CysAlisPro, Version 1.171.35.11; Agilent Technologies. Multiscan absorption correction with SCALE3 ABSPACK scaling algorithm.

[22] G.M Sheldrick. Acta Cryst. Sect. C

, $71(2015) 3$.

[23] CLSI, Methods for Dilution Antimicrobial Susceptibility Tests for Bacteria That Grow Aerobically; Approved Standard-Ninth Edition. CLSI document M07-A9., Clinical and Laboratory Standards Institute, Wayne, PA, (2012). https://clsi.org/media/1632/m07a10 sample.pdf.

[24] CLSI, Performance Standards for Antimicrobial Susceptibility Testing; Twenty-Fifth Informational Supplement. CLSI document M100-S25 (ISBN 1-56238-989-0 [Print]; ISBN 
1-56238-990-4 [Electronic]), Clinical and Laboratory Standards Institute, (2015). http://www.medsci.cn/webeditor/uploadfile/201505/20150518150013313.pdf. 